\title{
Return to education and financial value of investment in higher education in Indonesia
}

\author{
Yubilianto ${ }^{1,2^{*}}$ (D)
}

\section{${ }^{*}$ Correspondence:}

yubilianto@g.mbox.nagoya-u. ac.jp; yubilianto@gmail.com

${ }^{1}$ Graduate School

of International Development (GSID), Nagoya University,

Furo-cho, Chikusa-ku,

Nagoya 464-8601, Japan

Full list of author information

is available at the end of the article

\begin{abstract}
While there is extensive literature discussing the return to education using the remarkable semi-log Mincer equation, very few studies utilize the full discounting method to examine the impact of education investment from an individual perspective. This paper tries to analyze the return to higher education in Indonesia through the full discounting method mainly using the Indonesia Family Life Survey wave 5 (IFLS-5) and Synthetic Work-life Earnings (SWE) estimation. The results indicate that the median college graduate workers earn about $60 \%$ higher salary than that of secondary school leavers. With 4 years to complete a college degree, this figure indicates that the return to higher education is implicitly around 15\%, which is similar to the result of the Mincer earnings equation analysis. Moreover, it takes at least 14 years of working time to compensate for the investment in getting a bachelor's degree. These findings suggest that households should consider spending their money for university education. Likewise, the government and financial institutions can provide a better loan policy for higher education.
\end{abstract}

Keywords: Return to education, The full discounting method, Indonesia Family Life Survey (IFLS), Synthetic work-life earnings (SWE) estimate

\section{Introduction}

To some people, achieving a higher level of education is necessary as it leads to a better career and higher-earnings Card (1999). To some extent, this is quite reasonable. Despite typical patterns that income increases following the length of work at a decreasing rate, there is also a tendency that skilled workers earn more than unskilled workers (Becker 1962). This skill can be obtained either through on-the-job-training or schooling. This indicates that investment in education affects income positively to some extent. However, not all people can afford to go for schooling because of financial reasons, especially in developing countries (Chimombo 2005; Kurihara et al.2008).

Based on the Statistics Indonesia, the average percentage of monthly education expenditure to total non-food spending from 2000 to 2015 was around $8 \%$, while the amount increases around 16\% per year (Badan Pusat Statistik 2019). This relatively large amount of money is one of the primary considerations for parents to have their children attained a specific education level, especially for higher education, where a person needs to sacrifice more money as well as time. Moreover, the earnings benefit of having 
a higher degree is still uncertain, while the expenditure incurred is unavoidable. Chen (2002) explains that education investment is risky because of the difficulties in predicting estimated income and unemployment possibilities. As a result, parents, like investors, tend to expect a higher rate of return to compensate for this risky investment.

There are two conventional methods to measure the rate of return of investment in education from an individual perspective, namely the full discounting method and the Mincerian earnings function method. Many studies utilize the latter due to its simplicity rather than the full discounting method. While the Mincerian earnings function depends on econometric analysis, the full discounting method resembles the cost-benefit analysis that is mainly used to calculate the rate of return of a project.

Prior studies estimated that the average rate of return to education in Indonesia is around $10 \%$. All studies so far are derived from the Mincerian earnings equation. However, Layard and Psacharopoulos (1979) argue that this method is less reliable than the full discounting method since it neglects the cost of schooling. Therefore, there is a possibility that the actual rate of return to education is lower than $10 \%$.

This study mainly attempts to investigate the rate of return to education in Indonesia using the full discounting method. The research limits the scope of the study within tertiary education since this level is the most costly among the educational levels. Investing in higher education assumes the increasing value of its graduates, which can be traced from the higher earnings of college graduates compared to secondary leavers (Psacharopoulos 1972).

In this paper, the costs of college (tuition fee) are extracted from the actual cost of higher education and classified under low and high cost. This classification represents the range of investment in tertiary education to provide a better result to help Indonesian households determine optimal school level choices. Additionally, this paper utilizes the Mincer earnings equation for comparison.

The next section will mainly discuss the full discounting and the Mincerian earnings equation method as well as some findings regarding the rate of return to education in Indonesia. In Sect. 3, the conceptual framework of this study, as well as the data used, will be discussed. Following the conceptual framework and data handling, Sect. 4 will present an empirical analysis, and the remaining section will discuss the findings and their implications.

\section{Literature review}

Currently, micro-data are abundantly available for some countries so that researchers are capable of calculating the return to education. The most popular method to derive the rate of return to schooling is through applying an earnings equation, which was introduced by Mincer (1974), who argues that one's log earning is a function of years spent on education and the quadratic function of one's experience. Using 1960 US Census data, he found that the return to education is $10 \%$, while experience was found to be around $8 \%$. This equation became a widely accepted instrument to examine the relationship between education and earnings. Due to its simplicity and micro-data availability, there are plenty of researchers who apply this methodology. 
For instance, George Psacharopoulos, as one of the most prominent researchers on the topic of return to education, frequently uses the Mincer earnings equation. He found that, generally, the return to education is positive, around $10 \%$ across countries. High-income countries tend to have lower return to education compared to that of low or middle income countries; and males are likely to have a lower rate of return to schooling compared to their female counterparts (see Psacharopoulos 1981, 1985, 1994; and Psacharopoulos and Patrinos 2004).

Montenegro and Patrinos (2014), based on the World Bank's World Development Report, which covered 139 countries from 1970 to 2013, found that the return to schooling is $10.1 \%$ on average. In a more recent year, Patrinos (2016), through the Mincer earnings equation, exhibits that the average returns to education are around 5 to $8 \%$ globally. However, using a different proxy, he found that the global returns to higher education are approximately $17 \%$ on average. This level yields the highest rate, whereas the second position is the primary level, and the secondary level is the last. One of the latest studies indicates almost a similar result that the world average returns to education are around 8.8\% Psacharopoulos and Patrinos (2018).

Currently, Indonesia also provides a considerable amount of micro-data, which allows examining the return on education. By combining these micro-data and the prominent Mincer earnings equation, many studies have been conducted to investigate the rate of return to education in Indonesia. For example, Deolalikar (1993) used the combination of the National Socioeconomic Survey (SUSENAS) from 1987 and Village Potential module of the Economic Census from 1986 to analyze the demand for schooling as well as return to education. In particular, this study found that return to schooling for primary school is around $10 \%$, while the secondary and tertiary education tend to yield higher returns of up to $20 \%$.

Another study was conducted by Duflo (2001), who found that the rate of return to education in Indonesia is about 6.8 to $10.6 \%$. Instead of using years of schooling or educational attainment as a proxy for education, she used variation in education generated by Indonesian government school construction programs during the 1970s. Similarly, Comola and Mello (2010) also uses the same proxy as an instrumental variable to avoid endogeneity issues. They combined those data with the National Socioeconomic Survey (SUSENAS) from 2004 and found that the return to education in Indonesia ranges from 9 to $10.8 \%$.

Patrinos et al. (2006) found that average return to schooling in Indonesia is around $11.4 \%$, while the average return to education for East Asia is approximately $14.5 \%$. They applied quantile regression to investigate whether or not an investment in education adversely affects income distribution by analyzing some countries in East Asia and Latin America.

Purnastuti et al. (2013) used two data sets from the Indonesia Family Life Survey (IFLS), which was conducted in 1993 (IFLS-1) and 2007-2008 (IFLS-4), to examine the declining rate of return to education. The results showed that the return to schooling slightly decreases across all levels of education except for higher education. The return to tertiary education for females rose from around $5.1 \%$ in 1993 to $8.7 \%$ in 2007/2008; while for males, it slightly increased from 6 to $6.8 \%$. Using the same IFLS 4 data, Dumauli (2015) found that the return on education in Indonesia was between 10 
and $12 \%$ using Ordinary Least Square (OLS). When she implemented the Household Fixed Effect method using sibling data, the return on education significantly dropped to only $5 \%$.

Other than implementing the Mincer earnings equation, we can also utilize the full discounting method to measure the rate of return to education. The full discounting method is a process of finding the discount rate that satisfies the flow of discounted benefits against the sum of expenditures at a specific point in time (see Psacharopoulos and Mattson 1998). It follows the typical human capital theory, which indicates that a return determines a decision for a person to invest in a specific level of education. The return can be obtained through comparing the discounted value of the expected future benefit from a person with a specific level of education and the costs of enrolling at that education level, including opportunity cost (Becker 1964).

The main hindrance to implementing the full discounting method is a lack of availability of reliable data. Hitherto, no longitudinal data exist that capture the same individuals with the necessary information to calculate their exact work-life earnings to examine the expected rate of return of investment in education.

However, there are some methods to construct age-earnings patterns to calculate the expected work-life earnings. For example, Psacharopoulos (1995) constructed total expected work-life earnings using the mean of earnings at a specific age and level education. In this research, he used 1989 household survey data in Venezuela and found that return to education for primary, secondary, and tertiary school is $29.4 \%, 10.2 \%$, and $12.4 \%$, respectively.

On the other hand, Kantrowitz (2007) implemented a synthetic work-life earnings (SWE) method to study expected work-life earnings when examining the profitability of investment in tertiary education in the United States (U.S.). In his research, he used the mean of earnings to approximate the work-life earnings. By combining the expected work-life earnings and data of average out-of-pocket cost, he found that investing in higher education yields more than $27 \%$ of financial value.

The SWE method itself was initially designed by the U.S. Census Bureau to approximate the earnings of individuals within groups or sub-groups. This methodology can be used to observe the work-life earnings gap between individuals through education attainment levels.

\section{Methodologies}

\subsection{Conceptual framework}

Unlike other related studies, this research tries to calculate the rate of return to education using the full discounting method. To approximate the expected work-life earnings, the SWE estimation is implemented. After finding the expected work-life earnings through SWE estimation, the next step is calculating the total cost required to attain tertiary education. These two variables are necessary to find the rate of return to education through the identification of the internal rate of return (IRR) analysis and net present value (NPV) analysis in the full discounting method.

Although the primary objective is to calculate the rate of return to education using the full discounting method, this study also examines the return to education through the Mincer earnings equation for comparison. This study will start from the return to 
education analysis using the full discounting method, and then move on to the Mincerian earnings equation. The framework of the analysis process in this paper is depicted in Fig. 1.

\subsubsection{Estimating work-life earnings through SWE}

Estimating work-life earnings is one of the main issues when dealing with examining the return to education through the full discounting method. As previously explained, the main hindrance of applying the full discounting method to calculate real work-life earnings is the unavailability of real data. However, the U.S. Census Bureau develops the so-called SWE estimate to approximate the earnings of individuals within groups or subgroups. This methodology can be used to observe the work-life earnings gap between individuals through education attainment levels. The terminology of work-life refers to a person's career period. The terminology of work-life is used instead of lifetime to avoid misunderstanding. Lifetime usually includes real situation information such as real career development, the actual age-life of a person, and the sudden work termination. SWE estimate is a methodology to construct future earnings of workers with specific categories for an entire work-life by only using a single point of cross-sectional data. Although it does not represent actual future earnings, this SWE estimate is reliable in giving clues about the magnitude of earnings differences amongst workers with different levels of educational attainment.

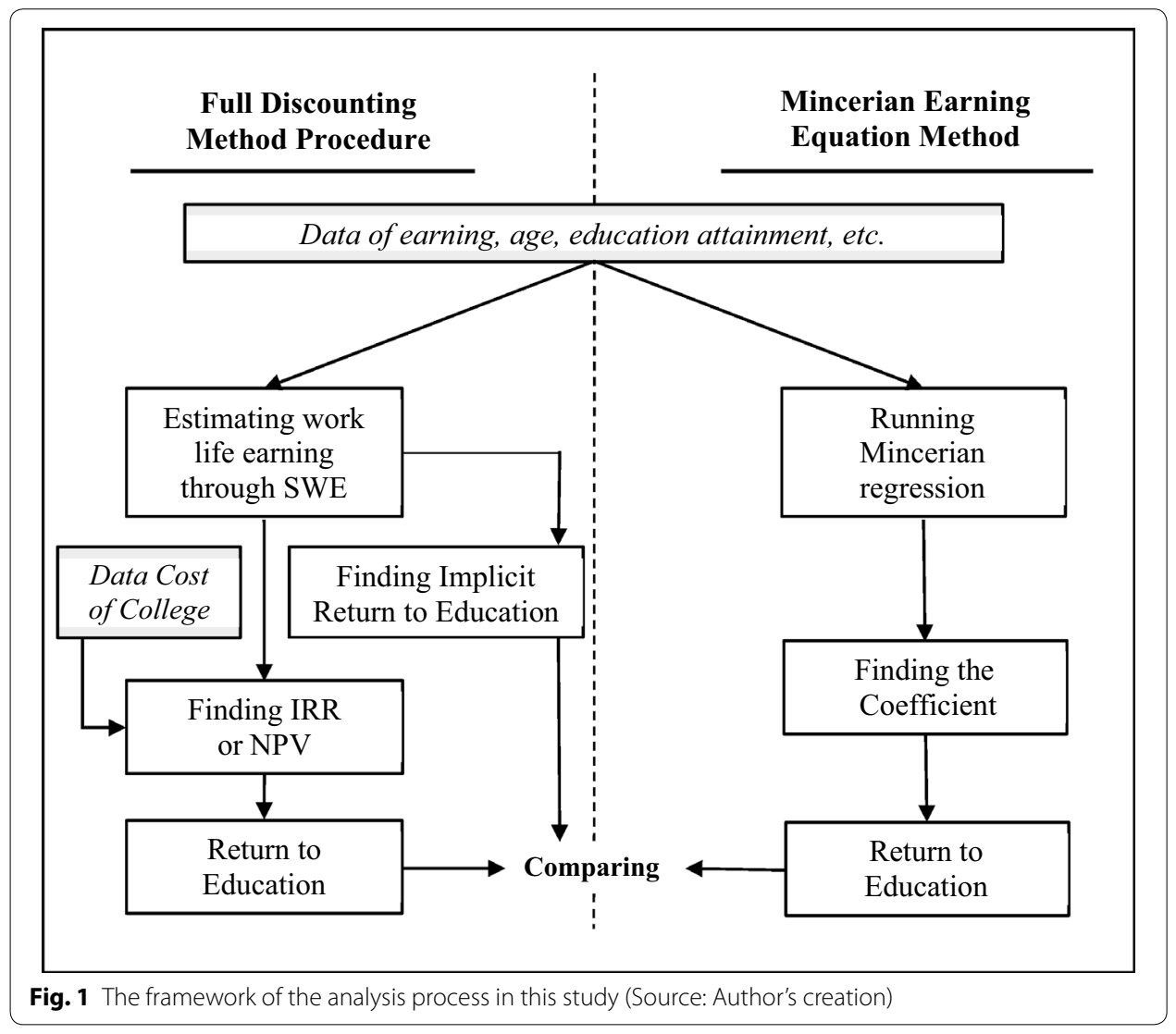


To examine earnings using the SWE estimate is relatively simple. First, all data are classified into a few cohorts where each cohort represents 5 years of ages with specific educational attainment. For example, for 15- to 64-year-old workers, who are considered as productive workers based on Statistics Indonesia, the data are classified into ten different cohorts. Cohort 1 gathers all earnings of workers for each educational attainment level between ages 15 and 20 years. Cohort 2 compiles workers with the same information between ages 21 and 24 years until the last cohort (cohort 10), which represents a group of workers' earnings with different educational levels between ages 60 and 64 years.

Secondly, the study finds the median of each cohort. Originally, the first SWE estimate, which was introduced by U.S. Census Bureau, is calculated using the average of workers' earnings within each cohort. However, the average earnings within the sample groups do not reflect the real average of workers' earnings because it is easily skewed to the left or right due to outliers. Thus, the median provides a better measurement to estimate the average of workers' earnings within a group since it is more reliable against outliers (Julian and Kominski 2011). After finding the median, the final step is multiplying each median of workers' earnings in each cohort by 5 . This procedure acts to calculate the total earnings for a worker within a specific age group and sums all of the cohorts to derive the SWE estimate, which can be expressed in the following equation:

$$
\mathrm{SWE}=\sum_{i=1}^{10}\left(\text { QuantEarnGr }_{i} \times 5\right),
$$

where SWE represents Synthetic Work-life Earnings for 50 years of work career, and QuantEarnGr $r_{i}$ is the median of the workers' earnings within-group $i$. Thus, with each cohort representing 5 years of ages, the SWE will be calculated as follows:

$$
\begin{aligned}
& (\text { Earnings } 15-19 \times 5)+(\text { Earnings } 20-24 \times 5)+(\text { Earnings } 25-29 \times 5) \\
& \quad+(\text { Earnings } 30-34 \times 5)+(\text { Earnings } 35-39 \times 5)+(\text { Earnings } 40-44 \times 5) \\
& +(\text { Earnings } 45-49 \times 5)+(\text { Earnings } 50-54 \times 5)+(\text { Earnings } 55-59 \times 5) \\
& +(\text { Earnings } 60-64 \times 5) .
\end{aligned}
$$

\subsubsection{Full discounting method analysis}

To calculate the rate of return on investment in tertiary education using the full discounting method, we need to identify the cost of college and the wage difference between college graduates and secondary leavers. After identifying the required components, we can calculate the IRR or NPV of the investment in tertiary education by comparing the cost and the benefit at a discounted value.

Technically, this methodology tries to find the rate of a discount that matches the cost of investing money to hold a bachelor's degree as well as its opportunity cost with the difference of earnings flows between college graduates and secondary school leavers for a specific age. Thus, to find the discount rate of an investment in a college, which assumes that one will spend four years in college and works or lives until 64 years of age, we can use the following equation: 


$$
\sum_{t=1}^{43} \frac{\left(W_{\mathrm{c}}-W_{\mathrm{s}}\right)_{t}}{(1+r)^{t}}=\sum_{t=1}^{4}\left(w_{\mathrm{s}}+\mathrm{Cc}\right)_{t}(1+r)^{5-t},
$$

where $W_{\mathrm{c}}$ refers to the age of college graduates, $W_{\mathrm{s}}$ is the age of secondary school leavers, $r$ indicates the rate of return, Cc explains the cost of college, and $t$ represents time.

Both IRR and NPV are popular to calculate the feasibility of a project in cost-benefit analysis; that is, to determine whether or not a project will be implemented or rejected. Since the full discounting method is similar to cost-benefit analysis, we can implement both these techniques. Technically, IRR is used by comparing the present value of all costs incurred during the project's life with the present value of all cash inflows or any economic value incurred during the project's life. The result will be represented as a percentage. Similarly, NPV also compares both the present value of cost and cash inflows through the project's life by summing those two factors. The result will be displayed in a monetary term. Additionally, NPV can be used to estimate the break-even point (BEP) or the moment where the cash inflows will fully cover the investment.

\subsubsection{Mincer earnings equation approach}

For this analysis, OLS regression is implemented on the Mincer earnings function to examine the return to education in Indonesia. Years of schooling is used as a proxy to analyze the return to education. Years of schooling is measured as the total years of one's life spent in study of formal education. In Indonesia, a person who completes elementary school has 6 years of schooling; while completing secondary school in senior high school has 12 years of schooling. In this study, a person who graduated from college is considered to have 16 years of schooling. College student in this study only refers to undergraduate students since workers who earned master or doctoral degrees were not included due to a lack of data availability. Moreover, to observe the different impact of additional years of schooling to earnings between males and females as well as urban and rural areas, the basic Mincer equation is modified as follows:

$$
\ln \left(\text { earnings }_{i}\right)=\beta_{1}+\beta_{2} \operatorname{yos}_{i}+\beta_{3} \exp _{i}+\beta_{4} \exp _{i}^{2}+\beta_{5} \text { tenure }_{i}+\beta_{6} \text { tenure }_{i}^{2}+\beta_{7} \text { female }_{i}+\beta_{8} \text { urban }_{i}+\varepsilon_{i},
$$

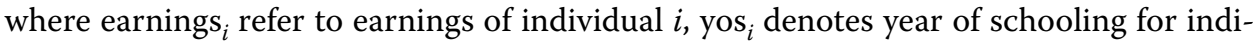
vidual $\mathrm{i}, \exp _{i}$ represents experience of individual $i$, tenure ${ }_{i}$ corresponds to job tenure for individual $i$, female ${ }_{i}$ is dummy variable for the gender of individual $i$, urban $_{i}$ is dummy variable for the area of individual $i$, and $\varepsilon_{i}$ is the error term. Experience in this equation, which is written as $\exp _{i}$ indicates the number of years of individual $i$ after graduating from last attended school. The initial year for a child to enroll in elementary school in Indonesia is 6 years old. Therefore, to derive a person's experience, I utilize the age of individual i subtracted by years of schooling and 6 years. Additionally, a tenure that is written as tenure ${ }_{i}$ exhibits the present job experience.

Other than years of schooling as a proxy for analyzing return to education, a similar methodology used by Purnastuti (2013) is also implemented. Some dummy variables for different levels of education are applied as a proxy to analyze the difference of impact at each level of education, from primary to tertiary education. This study does not include 
a person who is not in schooling or has not finish primary school. The equation can be written as follows:

$$
\begin{array}{r}
\ln \left(\text { earnings }_{i}\right)=\beta_{1}+\sum k \beta_{2} \text { Edu.Dum }_{i k}+\beta_{3} \exp _{i}+\beta_{4} \exp _{i}^{2} \\
+\beta_{5} \text { tenure }_{i}+\beta_{6} \text { tenure }_{i}^{2}+\beta_{7} \text { female }_{i}+\beta_{8} \operatorname{urban}_{i}+\varepsilon_{i}
\end{array}
$$

where $E d u . D_{u m}$ comprises the dummies for educational level $k$. Similar with Eq. (3), $\exp _{i}$ refers to the experience of individual $i$, tenure ${ }_{i}$ represents job tenure for individual $i$, female $_{i}$ is dummy variable for the gender of individual $i$, urban $_{i}$ is dummy variable for the area of individual $i$, and $\varepsilon_{i}$ is the error term.

To calculate the return to education at the $k$ th level of education based on the equation, we can consider the Sakellariou (2003), El-Hamidi (2005), and Kimenyi et al. (2006) formulation as follows:

$$
r_{k}=\frac{\left(\beta_{k}-\beta_{k-1}\right)}{\Delta n_{k}}
$$

where $r_{k}$ refers to return to education at the $k$ th level of education, $\beta_{k}$ refers to a coefficient of $k$ level of education, and $\Delta n_{k}$ represents the difference of years of schooling between $k$ level of education and $k-1$ level of education. Therefore, this equation measures the marginal return of education $k$ by dividing the marginal coefficient of the specific level of education and the difference of years of schooling for $k$ level of education and $k-1$.

\subsection{Data source and handling}

Generally, this study uses only two sources of primary data: first, data for calculating the earnings as well as its derivatives such as educational attainment, age, and experience. The other data are utilized for deriving the costs of college. For the first part, this study mainly utilizes the IFLS-5 (RAND 2016), which is the most recent available data published by Research and Development (RAND) in collaboration with Survey Meter to construct the work-life earnings estimation. RAND itself is an independent non-profit organization that was established over 70 years ago for dealing with research and analysis throughout the world related to broad issues such as education, energy, and health. Data on the costs of college, which refer to any expenses to get a higher education, mainly come from the Indonesia Ministry of Research, Technology, and Higher Education Decree as well as other sources.

\subsubsection{Data on earnings}

Data to estimate earnings are based on IFLS-5. This IFLS-5 was conducted in 20142015, where the initial research was conducted in 1993. Between 1993 and 2014, RAND also published IFLS-2 to IFLS-4, which took place in the years 1997, 2000, and 2004, respectively. The IFLS covers a sample of 16,204 households spread across 13 provinces out of 34 provinces in Indonesia on the islands of Java, Sumatra, Bali, West Nusa Tenggara, Kalimantan, and Sulawesi, which encompass approximately 83 percent of the Indonesian population and much of its heterogeneity. The IFLS-5 itself covers 50,148 
individuals across those provinces. Its richness in respondents' data makes it useful for analysis. These data are used for both analyzing return to education with the full discounting method and the Mincerian earnings equation method.

\subsubsection{Data on the cost of education}

In Indonesia, colleges are classified into two different types, namely public and private colleges. However, both types of universities still belong to the same Ministry of Research, Technology, and Higher Education. The most apparent difference between these two types of colleges is the cost of education. Typically, the tuition fees of private colleges are more expensive than those of public colleges.

For calculating the cost of college, tuition fee for public colleges is based on the Ministry of Research, Technology, and Higher Education Decree Number 22 (2015) which exposed the cost for the years 2014-2015. This study will exhibit the cost of public college from the top 10 best colleges in Indonesia. For the private university, the tuition fee comes from the respective universities' websites.

In this study, the cost of college for both public and private college is divided into lowcost and high-cost groups for analytic purposes. For public colleges, the low-cost group represents a highly subsidized tuition fee, while the high-cost group represents a low (or not) subsidized tuition fee. For private colleges, there are some assumptions to display high and low groups, such as assigning $10 \%$ of the cost of high-cost private colleges to represent low-cost private universities. For costs other than tuition fees, it will follow the average costs of the low and high cost of public colleges.

For both types of universities, expenses other than tuition fees such as book expenses and student living expenses refer to 2004-2005 educational expenditures provided by Wicaksono and Friawan (2008) after being adjusted by inflation to represent the 2014 price.

This research will focus only on 4 years of education that cover obtaining a bachelor's degree in college.

\section{Empirical results and discussion}

\subsection{Data characteristics}

\subsubsection{Data on earnings}

Although the total respondents reached 50,148 persons from the IFLS-5 raw data, the total number of workers who fall under the category between 15 years old and 64 years old is only less than half of the sample or only 24,489 persons to be precise. Based on the work category and educational attainment, those workers' statistics are shown in Figs. 2, 3, respectively.

From Fig. 2, it shows that mainly workers who meet the criteria are predominantly working as a private worker who covers $34 \%$ of total respondents under the category of $15-64$-year-old; while only $2 \%$ of workers who work as a self-employed with permanent workers represent the smallest portion in this survey. Between those two categories, some workers work as a casual worker in agriculture (3\%), government worker (7\%), casual worker not in agriculture (8\%), unpaid family worker (11\%), self-employee (17\%) and self-employed with unpaid family worker/temporary worker (18\%). 


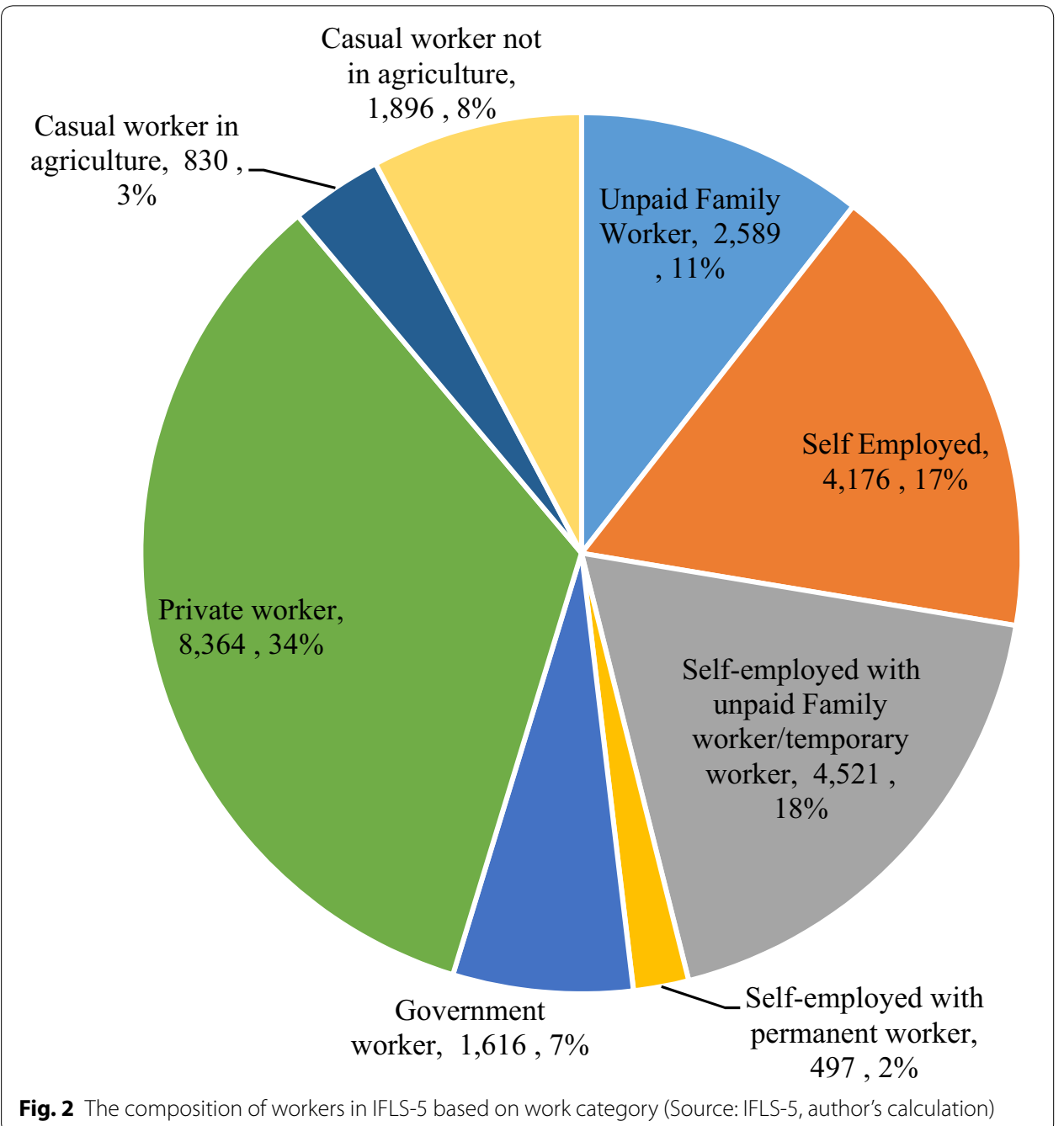

From the perspective of educational attainment, as shown in Fig. 3, the category is dominated by senior high school degree workers with $27 \%$ of the total respondents. Workers who hold at least a diploma degree is only $14 \%$, with the composition of diploma holders, bachelors, and graduates totaling $6 \%, 7 \%$, and $1 \%$, respectively. The remaining workers who did not get a degree or did not attend school and finished from only primary education are approximately $20 \%$.

Since the primary objective is to analyze the return to higher education, there are some important assumptions and treatments in handling raw data from IFLS-5, specifically when dealing with respondent criteria and the amount of wages or salaries. First, only workers aged 15-64 years who last month received a salary or wage are included in the samples. Secondly, data for wages are taken from monthly wages only from primary work, which are received by respondents from employers when considering the number of working hours. Thirdly, to measure the impact of educational attainment, all wages from individuals have been adjusted to be full-time workers with the assumption of $8 \mathrm{~h}$ of working time and 22 working days in a month as regular 


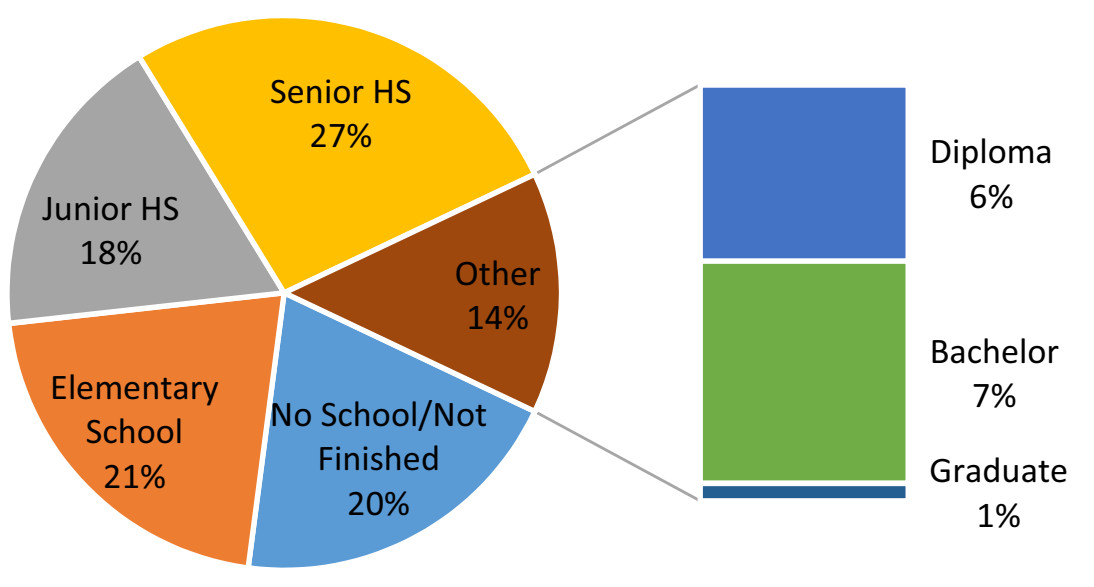

$$
\begin{aligned}
& \text { - No School/Not Finished }=\text { Elementary School } \quad \text { Junior HS } \\
& \text { - Senior HS } \quad \text { Diploma } \quad \text { Bachelor }
\end{aligned}
$$

- Graduate

Fig. 3 The composition of workers in IFLS-5 based on educational attainment (Source: IFLS-5, author's calculation)

monthly working hours in Indonesia. Moreover, data for government employees, which is around $7 \%$ of the total sample, are omitted since the salary is predetermined nationally by regulation. By applying these specifications, the total sample plummets from 24,489 individuals to only 14,852 individuals. Lastly, since the number of workers with tertiary education is not sufficient to be analyzed for each group, diploma and bachelor holders are merged under a group of colleges since its nature is similar. However, graduate degree holders are omitted in this research. Related to the classification to estimate the SWE, due to insufficient sample size, some analyses of groups or subgroups will use a 10-year cohort instead of a 5 -year cohort.

To understand the characteristics of the earnings for workers in Indonesia as well as for further earnings difference analyses, the workers are classified not only by educational attainment but also based on gender and location. The summary is shown in Table 1.

This table exhibits that the composition of male and female respondents is almost equal at each level of educational attainment. Some categories are dominated by females with more than $62 \%$ compared to the males who make up only about $37 \%$. These groups are the not-schooling group and college graduates group. Based on location, it also clearly shows that the more educated workers tend to be higher in urban areas compared to rural areas.

\subsubsection{Data on the cost of education}

The system of education in Indonesia allows a person to continue to tertiary education after finishing his/her secondary education. Referring to the Law of National Education System Number 20 (2003), a person can generally pursue tertiary education after 
Table 1 The composition of workers based on categories and subcategories. Source: IFLS5, author's calculation

\begin{tabular}{|c|c|c|c|c|}
\hline \multirow[t]{2}{*}{ Last school attended } & \multicolumn{2}{|l|}{ Gender } & \multicolumn{2}{|c|}{ Urban/rural } \\
\hline & Male & Female & Urban & Rural \\
\hline \multirow[t]{2}{*}{ No school/not finished } & 1821 & 3086 & 1953 & 2954 \\
\hline & (37.1\%) & $(62.9 \%)$ & $(39.8 \%)$ & $(60.2 \%)$ \\
\hline \multirow{2}{*}{ Elementary school } & 2457 & 2728 & 2498 & 2687 \\
\hline & $(47.4 \%)$ & $(52.6 \%)$ & $(48.2 \%)$ & $(51.8 \%)$ \\
\hline \multirow[t]{2}{*}{ Junior HS } & 2169 & 2237 & 2330 & 2076 \\
\hline & $(49.2 \%)$ & $(50.8 \%)$ & $(52.9 \%)$ & $(47.1 \%)$ \\
\hline \multirow[t]{2}{*}{ Senior HS } & 3414 & 3131 & 4466 & 2079 \\
\hline & $(52.2 \%)$ & $(47.8 \%)$ & $(68.2 \%)$ & $(31.8 \%)$ \\
\hline \multirow[t]{2}{*}{ Diploma } & 612 & 850 & 1036 & 426 \\
\hline & $(41.9 \%)$ & $(58.1 \%)$ & $(70.9 \%)$ & $(29.1 \%)$ \\
\hline \multirow[t]{2}{*}{ Bachelor } & 692 & 1148 & 1316 & 524 \\
\hline & $(37.6 \%)$ & $(62.4 \%)$ & $(71.5 \%)$ & $(28.5 \%)$ \\
\hline \multirow[t]{2}{*}{ Graduate } & 66 & 78 & 120 & 24 \\
\hline & $(45.8 \%)$ & $(54.2 \%)$ & (83.3\%) & $(16.7 \%)$ \\
\hline
\end{tabular}

spending 9 years on primary education (elementary school and junior high school) and another 3 years in secondary education via senior high school. One who is eager to continue to tertiary education will spend around 4 years to get a bachelor's degree, another 2 years for a master's degree, and three more years for a doctoral degree. All in all, one shall spend 21 years in a school to be at the pinnacle of the education system.

Based on the Ministry of Research, Technology, and Higher Education Decree Number 22 (2015), public universities are allowed and required to classify the tuition fee into a few categories based on the financial ability of the prospective students or their sponsors. The tuition fee is a single component cost of education without any additional fees, and the amount varies amongst public colleges and faculty or study programs. The public colleges also disclose the budget that should be allocated for the college for providing education and for each student. Therefore, the difference between the budget and the tuition fee imposed on a student represents the amount of subsidy by either government (if the tuition fee is lower than the budget cost) or student (if the tuition fee exceeds the budget cost). The result is shown in Table 2 .

From this table, we can observe that from the 10 best universities, based on Ministry of Research, Technology and Higher Education's classification, under 474 study programs, the average budget that should be allocated by the college for giving education or each student until he/she finishes his/her study is ranging from around Rp50 million to Rp100 million (about USD 4209 to USD 8419). These ten universities represent the best public colleges since there are no private colleges included in this list. However, the tuition fee that should be paid by prospective students varies from the lowest at only around Rp3.2 million to the highest at not less than Rp91 million (about USD 269 to USD 7661). This means that for the prospective student under the category where the government heavily subsidizes them, they will receive a benefit of up to 30 times the amount they pay. On the other hand, prospective students under the category of the most expensive 
Table 2 The cost of education and tuition fee from top 10 universities for the year 2014/2015. Source: Ministry of Research, Technology and Higher Education Decree Number 22/2015

\begin{tabular}{|c|c|c|c|c|c|c|}
\hline \multirow[t]{2}{*}{ No. } & \multirow[t]{2}{*}{ University } & \multirow[t]{2}{*}{$\begin{array}{l}\text { \#Study } \\
\text { Program }\end{array}$} & \multirow{2}{*}{$\begin{array}{l}\text { Average cost } \\
\text { of education } \\
\text { for each student } \\
\text { (in Rupiah) }\end{array}$} & \multicolumn{3}{|c|}{$\begin{array}{l}\text { Tuition fee/college } 4 \text { years (in } \\
\text { Rupiah) }\end{array}$} \\
\hline & & & & Lowest & Mid & Highest \\
\hline 1 & Universitas Gadjah Mada & 68 & $70,031,647$ & $4,000,000$ & $26,923,529$ & $47,211,765$ \\
\hline 2 & Institut Teknologi Bandung & 43 & $96,122,791$ & $3,200,000$ & $32,000,000$ & $80,000,000$ \\
\hline 3 & Institut Pertanian Bogor & 10 & $53,812,800$ & $4,000,000$ & $24,680,000$ & $51,040,000$ \\
\hline 4 & Universitas Indonesia & 52 & $64,022,000$ & $4,000,000$ & $20,000,000$ & $40,038,462$ \\
\hline 5 & $\begin{array}{l}\text { Institut Teknologi Sepuluh } \\
\text { Nopember }\end{array}$ & 24 & $65,192,000$ & $4,000,000$ & $26,000,000$ & $48,000,000$ \\
\hline 6 & Universitas Diponegoro & 51 & $55,511,059$ & $4,000,000$ & $33,137,255$ & $54,705,882$ \\
\hline 7 & Universitas Airlangga & 33 & $55,289,939$ & $4,000,000$ & $39,000,000$ & $91,757,576$ \\
\hline 8 & Universitas Brawijaya & 69 & $54,887,072$ & $4,000,000$ & $35,492,783$ & $54,232,464$ \\
\hline 9 & Universitas Hasanuddin & 69 & $98,238,377$ & $4,000,000$ & $15,420,290$ & $40,695,652$ \\
\hline \multirow[t]{2}{*}{10} & Universitas Negeri Yogyakarta & 55 & $63,123,491$ & $4,000,000$ & $23,563,636$ & $37,136,000$ \\
\hline & & 474 & $67,623,118$ & 3920,000 & $27,621,749$ & $54,481,780$ \\
\hline
\end{tabular}

tuition fees should pay almost double the budget allocation of the college for providing education.

Unlike public colleges, private universities have the autonomy to determine the tuition fee as well as other expenses that will be assigned to a prospective student. Therefore, the total cost will vary greatly. Some private universities have various schemes of tuition fees from Rp0 for the full scholarship (full fee exemption) to almost Rp600 million (or

Table 3 One year public and private universities' cost of college. Source: Author's compilation from various sources

\begin{tabular}{|c|c|c|c|c|c|c|c|}
\hline \multirow{3}{*}{$\begin{array}{l}\text { Special 'one-time' } \\
\text { or 'up-front' fees }\end{array}$} & \multicolumn{4}{|c|}{ Public colleges (in Rupiah) } & \multicolumn{3}{|c|}{ Private colleges (in Rupiah) } \\
\hline & \multicolumn{2}{|l|}{ Low } & \multicolumn{2}{|l|}{ High } & \multirow{2}{*}{$\begin{array}{l}\text { Low } \\
2014- \\
2015\end{array}$} & \multicolumn{2}{|l|}{ High } \\
\hline & $\begin{array}{l}2004- \\
2005\end{array}$ & $\begin{array}{l}2014- \\
2015\end{array}$ & $\begin{array}{l}2004- \\
2005\end{array}$ & $\begin{array}{l}2014- \\
2015\end{array}$ & & $\begin{array}{l}2004- \\
2005\end{array}$ & 2014-2015 \\
\hline \multicolumn{8}{|c|}{ Instructional expenses } \\
\hline Tuition & 300,000 & 980,000 & $1,000,000$ & $13,620,445$ & $4,339,300$ & $4,000,000$ & $43,393,000$ \\
\hline $\begin{array}{l}\text { Books and other } \\
\text { educational } \\
\text { expenses }\end{array}$ & 900,000 & $1,688,298$ & $1,350,000$ & $2,532,447$ & $2,110,373$ & $2,250,000$ & $4,220,745$ \\
\hline $\begin{array}{l}\text { Subtotal instruc- } \\
\text { tional expenses }\end{array}$ & $1,200,000$ & $2,668,298$ & $2,350,000$ & $16,152,892$ & $6,449,673$ & $6,250,000$ & $47,613,745$ \\
\hline \multicolumn{8}{|c|}{ Student living expenses } \\
\hline Lodging & 900,000 & $1,661,274$ & $9,000,000$ & $16,612,744$ & $9,137,009$ & $10,800,000$ & $19,935,293$ \\
\hline Food & $3,600,000$ & $9,984,756$ & $6,300,000$ & $17,473,324$ & $13,729,040$ & $8,100,000$ & $22,465,702$ \\
\hline Transportation & 315,000 & 540,618 & 450,000 & 772,312 & 656,465 & $2,250,000$ & $3,861,560$ \\
\hline $\begin{array}{l}\text { Other personal } \\
\text { Expenses }\end{array}$ & 800,000 & $1,652,355$ & $2,700,000$ & $5,576,697$ & $3,614,526$ & $3,600,000$ & $7,435,596$ \\
\hline $\begin{array}{l}\text { Subtotal } \\
\text { expenses of } \\
\text { student living }\end{array}$ & $5,615,000$ & $13,839,004$ & $18,450,000$ & $40,435,077$ & $27,137,040$ & $24,750,000$ & $53,698,151$ \\
\hline $\begin{array}{l}\text { Total cost to parent } \\
\text { and student }\end{array}$ & $6,815,000$ & $16,507,302$ & $20,800,000$ & $56,587,969$ & $33,586,713$ & $31,000,000$ & $101,311,896$ \\
\hline
\end{tabular}




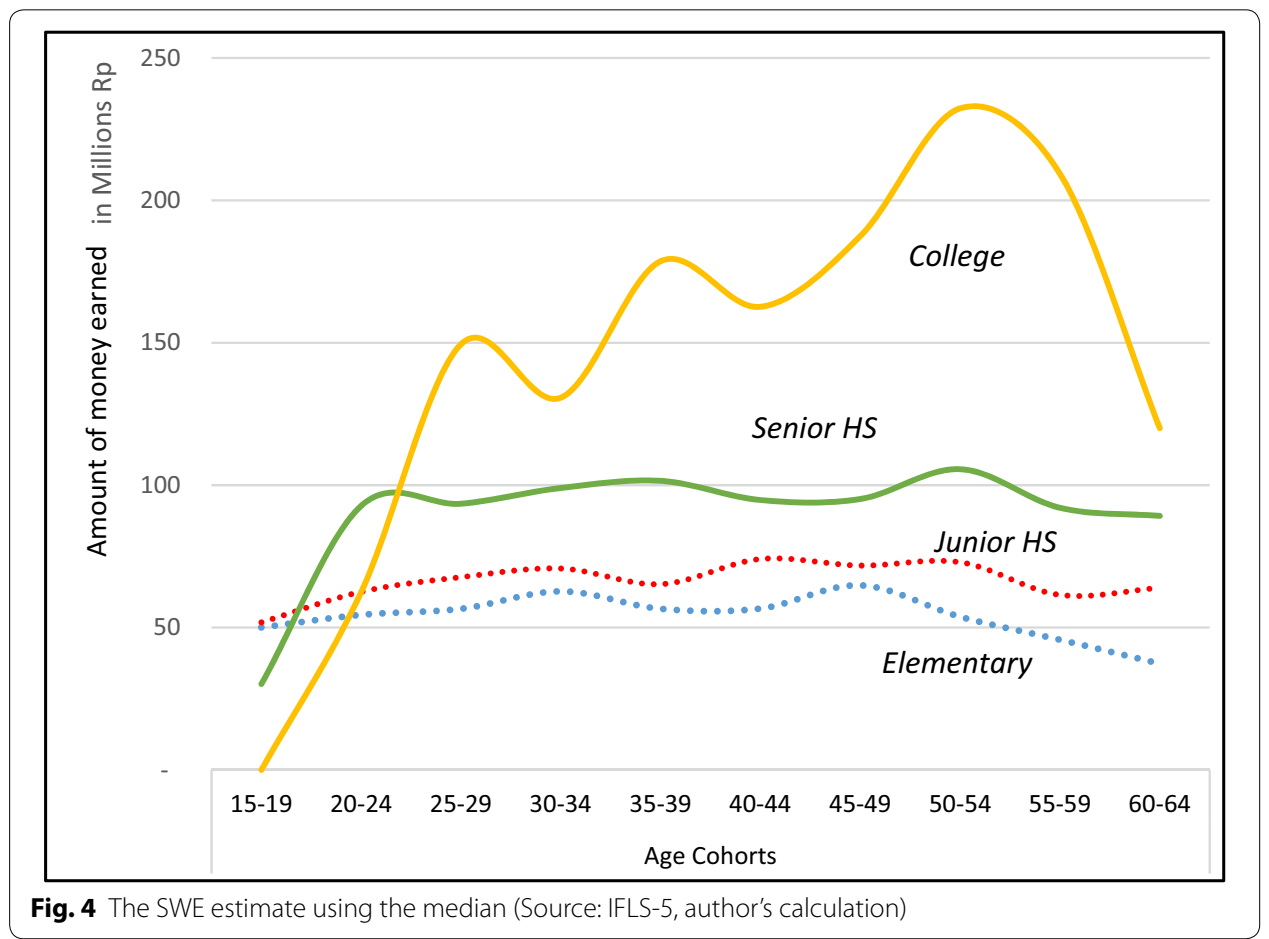

about USD 50,512) in the years 2014-2015. The most expensive one is the tuition fee of Trisakti University under the Medical Faculty for the bachelor's degree program.

Table 3 describes the detail expenses estimation for a student for studying a year in a college. Besides the tuition fee, any other expenses that should be borne by the prospective student, such as book expenses, lodging, food, and transportation, are also included in this estimation.

This table shows the differences between public and private college expenditures; that is, it shows the cost differences between public and private colleges. Public colleges are run and subsidized by the government while the private colleges are privately funded.

\subsection{Return to higher education based on full discounting method}

\subsubsection{Work-life earnings estimation based on SWE approach}

Figure 4 presents the estimation of the work-life earnings pattern for each educational attainment level based on Eq. (1).

From this figure, we can confirm the typical pattern of increasing income following the length of work at a decreasing rate with its peak around the age of 55-59 years.

The figure also shows that the college degree holder workers gain the highest earnings exceeding the rest of educational attainment level workers substantially. Confirming the suggestion by extensive literature, the result also exhibits that more educated workers tend to earn more than less educated ones. It clearly shows that a college degree worker earns more than senior high school degree workers. Besides, senior high school degree workers earn more than primary education degree workers 


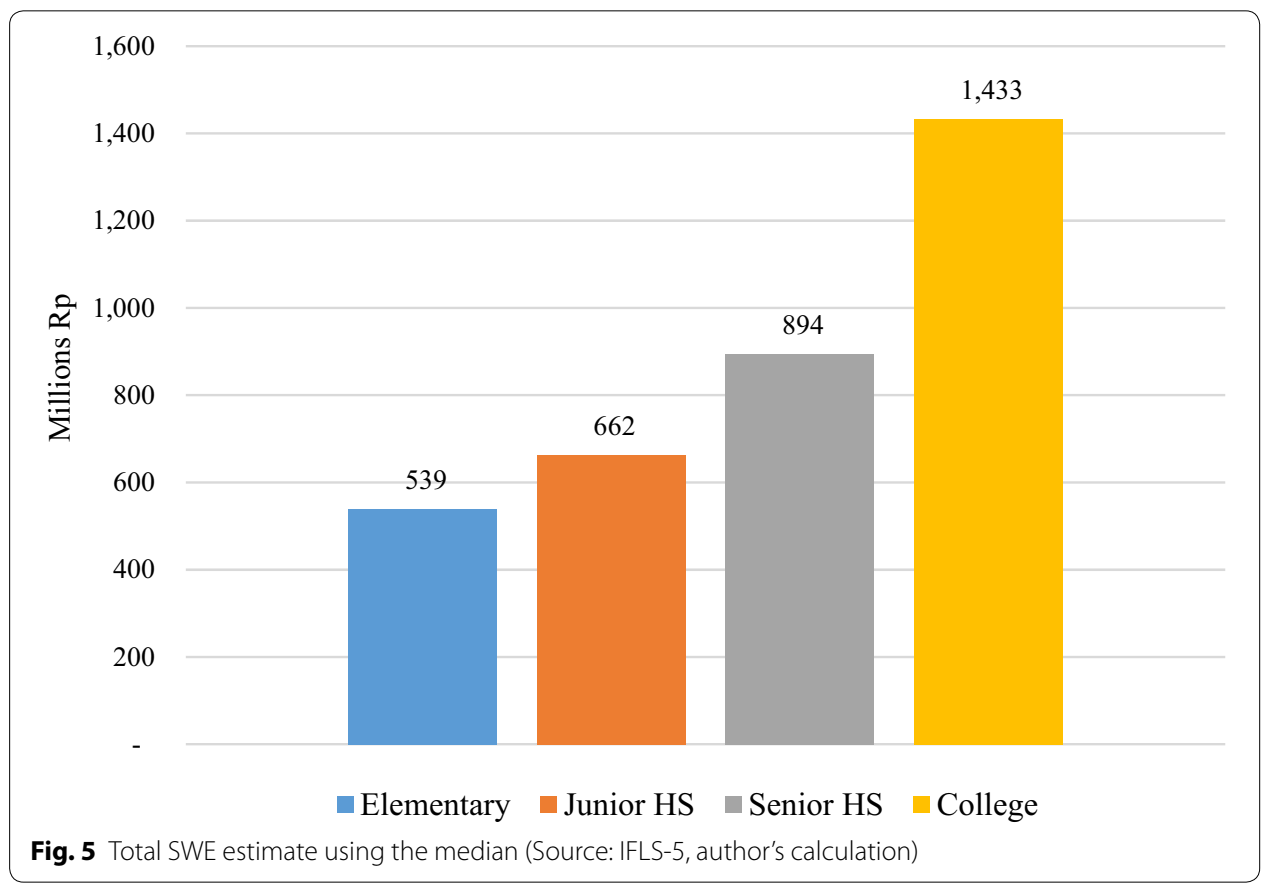

with elementary school graduates holding the last position in terms of work-life earnings. This finding agrees with Becker (1962) that not only is there a typical pattern of increasing income following the length of work at a decreasing rate but also a tendency for skilled workers to earn more than unskilled workers.

The College graduate will earn around 60\% more compared to that of senior high school graduates with the total amount of Rp 1433 million (around USD 120,640) for the median workers, while senior high school graduate workers only earn Rp 894 million (around USD 75,263). On the other hand, junior high school graduate and elementary school graduate workers earn around 18 and $37 \%$ less than secondary school leaver workers, as shown in Fig. 5.

The SWE estimate also allows us not only to compare categories (e.g., Educational attainment) but also to compare within subcategories such as gender and working location. However, due to the lack of sample data for analyzing subcategories, each cohort is classified based on 10 years of age difference rather than 5 years. The total earnings differences between classifying SWE into ten cohorts and five cohorts are around $0.2-5 \%$ for each education attainment level, as shown in Table 4.

Figure 6 below describes the earnings difference between male and female workers for their entire life. The SWE estimate clearly shows that male workers earn more than female workers at every level of educational attainment. The highest difference occurs on elementary school degree holders workers where males earn $48 \%$ more compared to female workers at the same level of education. It is most likely because in Indonesia, male workers as the head of a household support all of the family members within the household; thus, they often get additional income such as a family allowance by the employer.

The figure also shows the trend that the earnings difference between male and female workers decreases considerably as the level of education increases. In this case, at the junior high school level, the earnings difference between male and female 


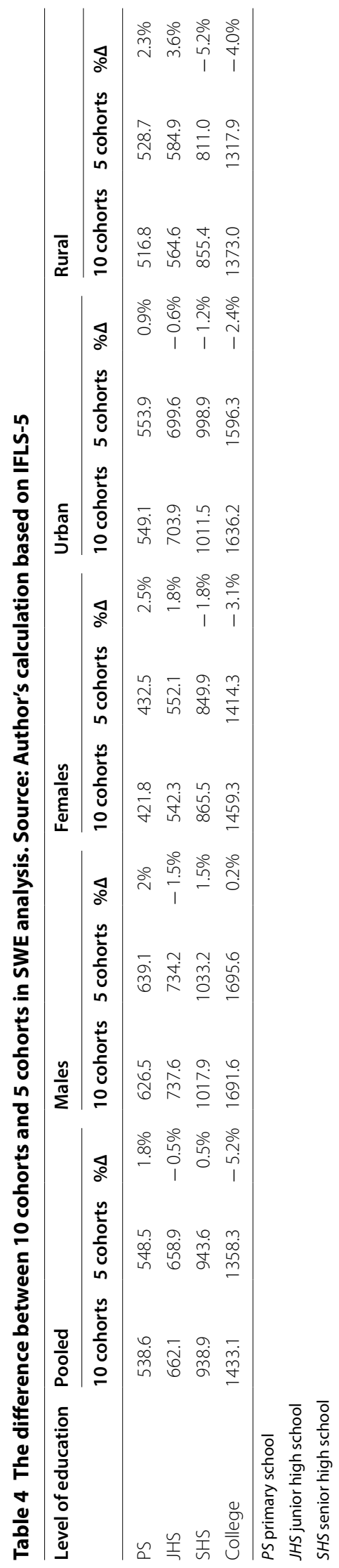




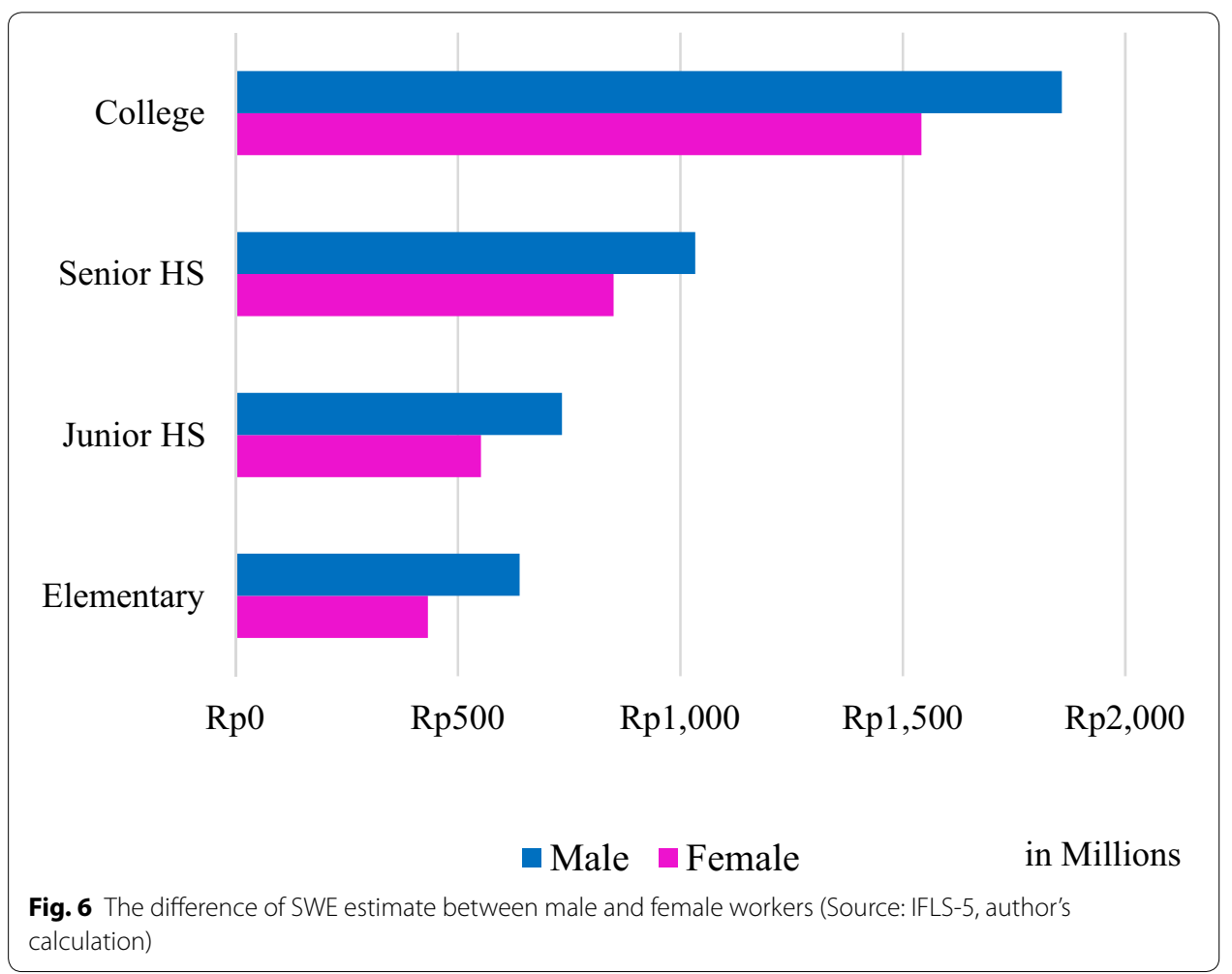

workers narrows to become $33 \%$. For senior high school degree and college degree holders, the gap of workers' earnings is around $20 \%$. This indicates that education can alleviate the power of bargain for a higher salary for female workers so that their earnings will approach being equal in amount to the earnings of male workers.

Figure 7 shows the difference between earnings of urban workers and rural workers. We can verify that at all educational attainment levels, whether elementary or college graduates, urban workers earn more than rural workers. In this figure, we can see that for more educated workers, there is a broader gap in earnings differences between urban and rural workers, which is around $20 \%$. However, elementary graduate workers in rural areas earn almost similar amounts to those who work in urban areas, with only around $5 \%$ difference.

Back to Fig. 5, if we put aside the cost of college, the results imply that, in general, the return to education for tertiary education is around $15 \%$. This number is obtained with the assumption of taking 4 years for finishing a bachelor's degree. In this case, we divide the percentage of earnings differences between college graduates and secondary leavers with the additional 4 years of schooling. For other education attainment levels, such as senior high school and junior high school, which take 3 years each, the return to education is around 14 and $8 \%$, respectively. Additionally, for males and females as well as rural and urban workers, the implicit return to education is shown in Table 5.

This implicit return to education refers to the short-cut method, which assumes flat age-earnings profiles. Therefore, the estimation of the rate of return to education is simply the difference between earnings on educational level $k$ minus earnings on 


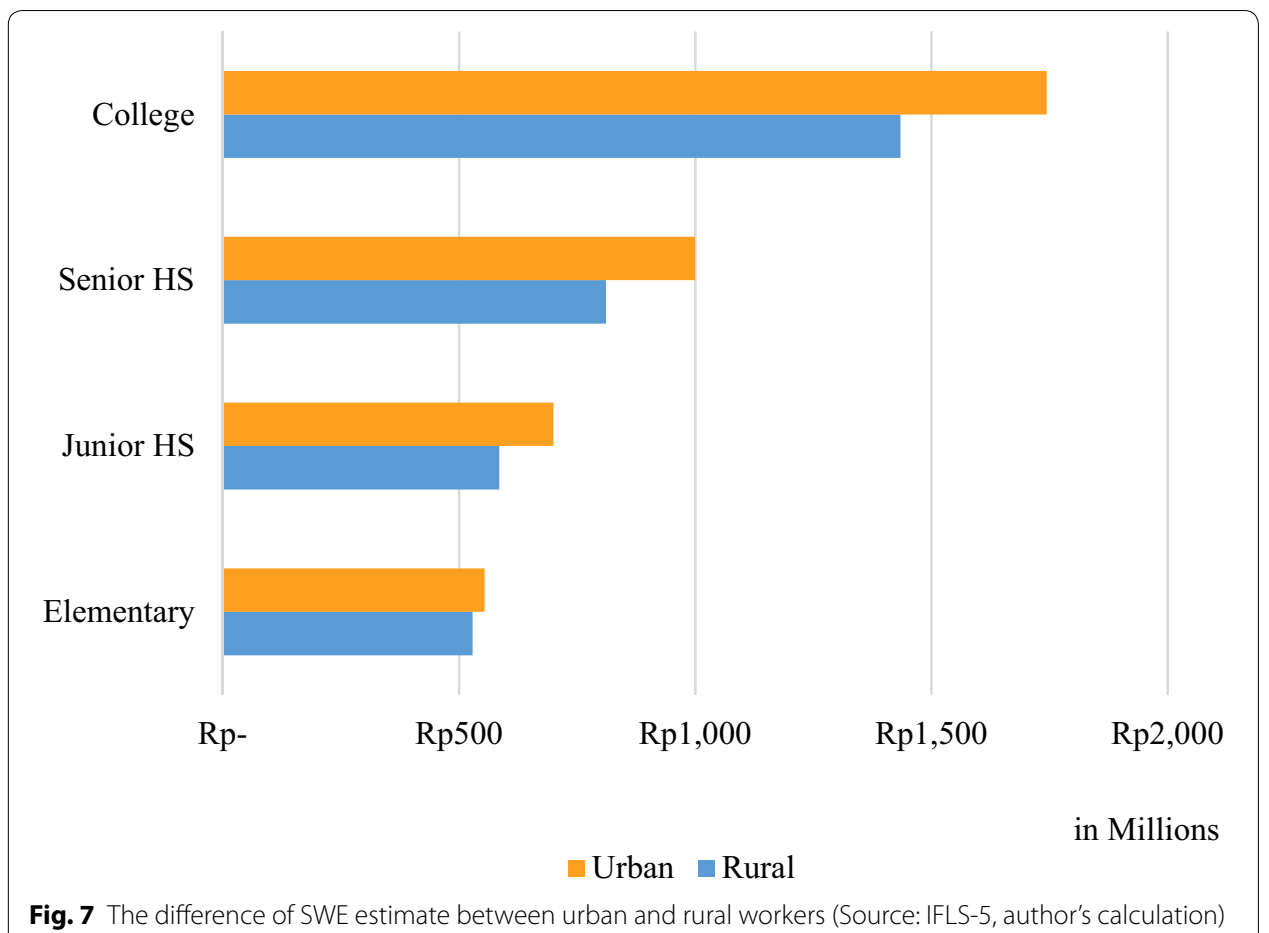

Table 5 Implicit return to education from SWE analysis. Source: Author's calculation based on IFLS-5

\begin{tabular}{lccccr}
\hline Level of education & Pooled & Male & Female & Urban & Rural \\
\hline Junior HS & $7.6 \%$ & $5.0 \%$ & $9.2 \%$ & $8.8 \%$ & $3.5 \%$ \\
Senior HS & $11.7 \%$ & $11.1 \%$ & $14.9 \%$ & $11.6 \%$ & $10.1 \%$ \\
College & $15.1 \%$ & $18.3 \%$ & $19.3 \%$ & $17.3 \%$ & $18.3 \%$ \\
\hline
\end{tabular}

educational level $k-1$ divided by $n$ years of schooling at educational level $k$ and earnings on educational level $k-1$ (see Psacharopoulos 1995).

From the perspective of marginal work-life earnings among each educational level within the same gender, it shows that the female workers tend to gain more advantages from continuing schooling. The implicit return to education of female college graduates is around $19.3 \%$, while males are only about $18.3 \%$. Both junior high school and senior high school graduates also exhibit the same pattern. The females obtain around $4 \%$ higher return to education compare to that of their male counterparts.

Within the same region, there are some variations in the implicit return to education. Using the SWE method, overall, urban workers tend to take more advantages from continuing schooling. In the urban area, the return to education of becoming junior high school, senior high school, and college graduates is $8.8 \%, 11.6 \%$, and $17.2 \%$, respectively, while the rural area provides a lower return, except for college graduates. Based on this method, the implicit return to higher education in rural areas is around $18.2 \%$. 
Table 6 The result of IRR and NPV on the full discounting method analysis (in Millions Rp). Source: Author's calculation

\begin{tabular}{|c|c|c|c|c|}
\hline \multirow[t]{2}{*}{ Items } & \multicolumn{2}{|c|}{ Public colleges } & \multicolumn{2}{|c|}{ Private colleges } \\
\hline & Low & High & Low & High \\
\hline \multicolumn{5}{|l|}{ Pooled } \\
\hline Direct cost & -66.0 & -226.4 & -134.3 & -405.2 \\
\hline Opportunity cost & -58.2 & -58.2 & -58.2 & -58.2 \\
\hline Benefit (Wc-Ws) & 606.8 & 606.8 & 606.8 & 606.8 \\
\hline IRR & $46.2 \%$ & $18.0 \%$ & $29.5 \%$ & $5.9 \%$ \\
\hline NPV & 482.6 & 322.3 & 414.3 & 143.4 \\
\hline BEP after & 14 years & 25 years & 19 years & 33 years \\
\hline \multicolumn{5}{|l|}{ Male } \\
\hline Direct cost & -66.0 & -226.4 & -134.3 & -405.2 \\
\hline Opportunity cost & -57.9 & -57.9 & -57.9 & -57.9 \\
\hline Benefit (Wc-Ws) & 786.8 & 786.8 & 786.8 & 786.8 \\
\hline IRR & $54.9 \%$ & $24.7 \%$ & $37.1 \%$ & $11.8 \%$ \\
\hline NPV & 662.9 & 502.6 & 594.6 & 323.7 \\
\hline BEP after & 10 years & 20 years & 15 years & 30 years \\
\hline \multicolumn{5}{|l|}{ Female } \\
\hline Direct cost & -66.0 & -226.4 & -134.3 & -405.2 \\
\hline Opportunity cost & -57.7 & -57.7 & -57.7 & -57.7 \\
\hline Benefit (Wc-Ws) & 704.2 & 704.2 & 704.2 & 704.2 \\
\hline IRR & $51.2 \%$ & $21.8 \%$ & $33.8 \%$ & $9.3 \%$ \\
\hline NPV & 580.5 & 420.2 & 512.2 & 241.3 \\
\hline BEP after & 16 years & 24 years & 20 years & 32 years \\
\hline \multicolumn{5}{|l|}{ Urban } \\
\hline Direct cost & -66.0 & -226.4 & -134.3 & -405.2 \\
\hline Opportunity cost & -57.9 & -57.9 & -57.9 & -57.9 \\
\hline Benefit (Wc-Ws) & 738.0 & 738.0 & 738.0 & 738.0 \\
\hline IRR & $52.8 \%$ & $23.0 \%$ & $35.2 \%$ & $10.3 \%$ \\
\hline NPV & 614.1 & 453.8 & 545.8 & 274.9 \\
\hline BEP after & 13 years & 22 years & 16 years & 31 years \\
\hline \multicolumn{5}{|l|}{ Rural } \\
\hline Direct cost & -66.0 & -226.4 & -134.3 & -405.2 \\
\hline Opportunity cost & -56.8 & -56.8 & -56.8 & -56.8 \\
\hline Benefit (Wc-Ws) & 623.1 & 623.1 & 623.1 & 623.1 \\
\hline IRR & $47.3 \%$ & $18.7 \%$ & $30.4 \%$ & $6.5 \%$ \\
\hline NPV & 500.2 & 339.9 & 431.9 & 161.0 \\
\hline BEP after & 24 years & 30 years & 28 years & 34 years \\
\hline
\end{tabular}

\subsubsection{IRR and NPV analysis}

The final stage of the full discounting method is calculating the return of investment in education by comparing the total benefit of continuing to higher education with all costs borne by the workers during their study. This analysis will implement both the IRR approach and NPV approach to calculate the return to education. Please bear in mind that both IRR and NPV methods emphasize the rate of return of monetary value invested in education rather than merely analyzing time spent for continuing schooling.

After identifying both work-life earnings estimation through SWE estimate and expenditures to continue to higher education, we can combine those variables to calculate the 
rate of return of investment to examine the financial value of tertiary education in Indonesia. By applying both expected income and expenditure into Eq. (5), we can calculate the value, as shown in Table 6.

The total work-life earnings, which is generated through SWE by using IFLS-5, is observed data and not projected income. Therefore, it is not necessary to estimate the present value as it already represents the real value.

As shown in Table 6, the return on tertiary education generally varies significantly around 5.9-46.2\%, depending on the choice of college. In this case, for those who are not eligible to enter public college with a large portion of subsidy (e.g., they do not belong to low-income families), the rate of return of the investment will be lower than $46.2 \%$. However, those who choose private colleges with its "high price" will still obtain more than a $5 \%$ return on investment. This scheme is highly dependent on the choice of college. Workers who are only capable of graduating from a public college with higher cost, that is, belong to a group that is not subsidized (or only partially subsidized), will earn about $18 \%$ return of investment.

From the cost-benefit analysis using the NPV method, we can assume that the interest rate is $8.5 \%$, which is derived from the average government bond interest rate in Indonesia. The result principally shows the same pattern that the higher NPV is acquired by workers who graduated from public college, which is heavily subsidized. In this case, the investment of the workers for continuing their education to tertiary education is fully paid back after 14 years of working after graduating from college. The lowest NPV is obtained by the workers who are graduated from a high-cost private college with only around Rp143.4 million (about USD 12,072) of work-life earnings. Therefore, the cost of college for these workers will be recovered after 33 years of working life.

Overall, male workers potentially have the highest rate of return to education. Using the IRR method and the assumption of the lowest cost of college, the return to education is approximately $55 \%$. Therefore, through the NPV method, the NPV is about Rp663 million (around USD 55,816) and will be BEP after only 10 years. The lowest one is rural workers. With the same assumption, IRR analysis indicates that the return to education for this group is around $47.3 \%$, and the NPV is around Rp500 million (about USD 42,094) with BEP after 24 years. If we use the high cost of college assumption, the return to education drops to $6.5 \%$ with NPV only around Rp161 million (about USD 13,554) and will be BEP after 34 years. This last scenario is the lowest return to education based on this analysis.

\subsection{Return to education based on mincer earnings equation approach}

Table 7 exhibits the result of OLS based on the Mincer earnings equation, as explained in Eqs. (3) and (4). All the data analyzed are based on IFLS-5 with similar data handling as with the SWE approach. Column (years) contains the result based on Eq. (3), where the years of schooling are utilized as the proxy. Meanwhile, the column (level) refers to Eq. (4), where the level of education is applied as the proxy.

Using years of schooling as a proxy, as described in Eq. (3), we can observe that one additional year of schooling will increase earnings by $8.9 \%$ in general. For male workers, the impact of getting one additional year of schooling is almost $2 \%$ higher 


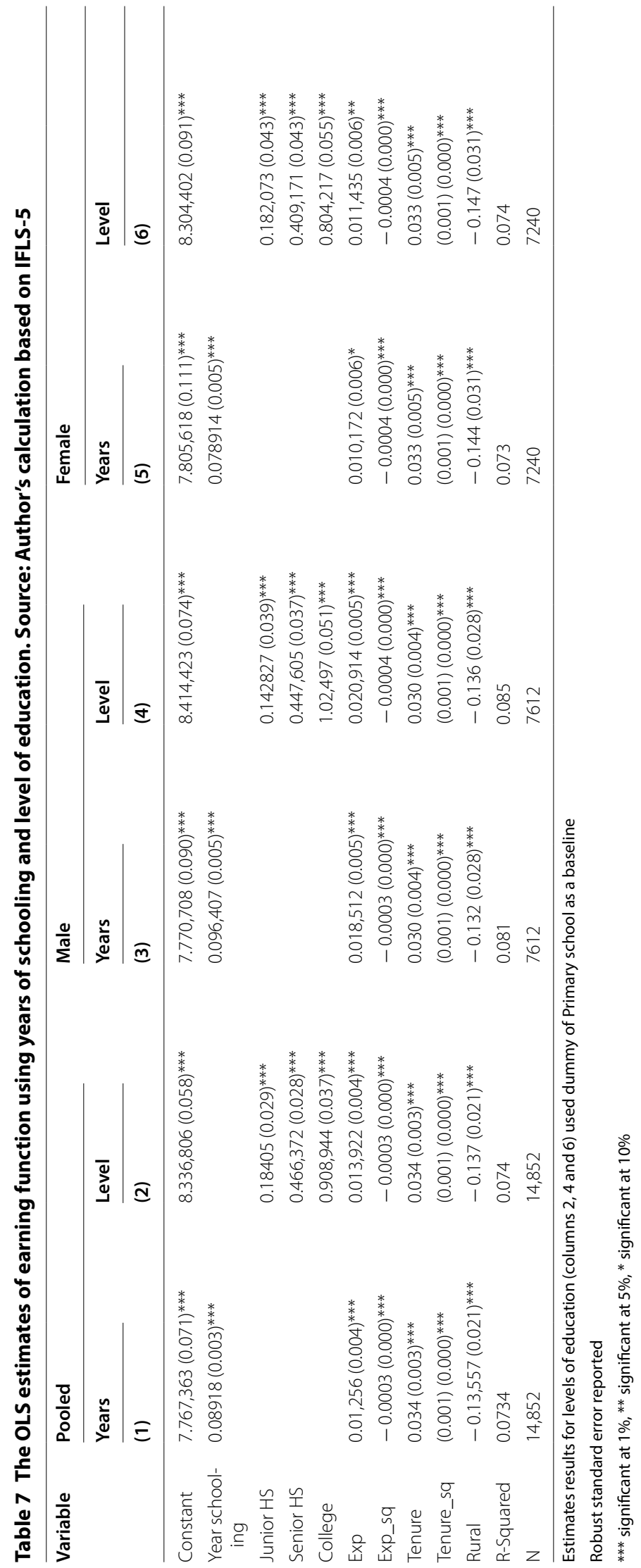




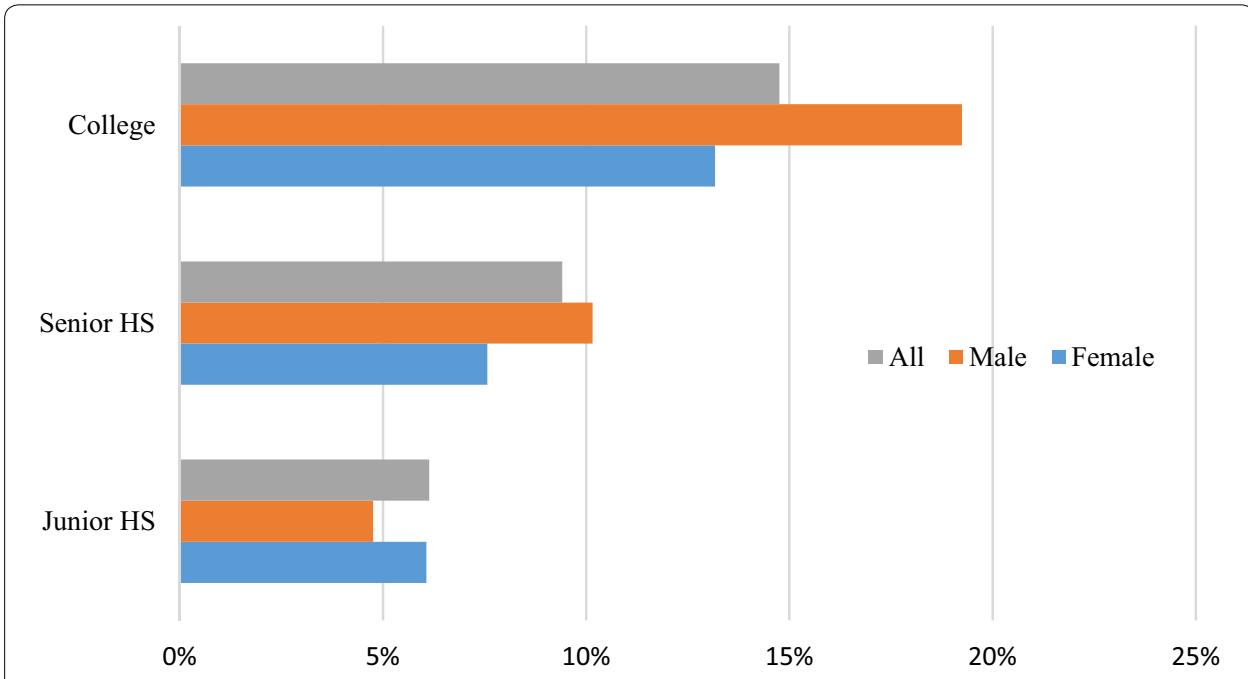

Fig. 8 Return to education, calculated from level of education as a proxy (Source: Author's calculation based on data on Table 4)

compared to that of female workers. In this case, female workers only generate $7.8 \%$, whereas male workers get $9.6 \%$. It indicates that getting additional years of schooling will give more benefits for males compared to that of females.

In terms of location, it clearly can be seen that working in a city will give more benefits compared to working in a village. From the analysis, rural workers will earn $13.5 \%$ less than their counterparts in urban areas. Specifically, urban male workers earn $13.2 \%$ more than rural male workers. Additionally, we can see that urban female counterparts even get an additional $1.2 \%$, which is $14.4 \%$, compared to that of rural female workers.

By applying Eq. (5) on the results in Table 4, we can calculate the impact of the additional level of education on earnings, as shown in Fig. 8 as follows:

From that figure, we find that getting a higher education will give the highest benefit, among other levels of education. In this case, return to education as a college graduate is $14.8 \%$. This number is derived from the assumption of 4 years of schooling in the college. In other words, college graduate workers earn $59 \%$ higher compared to secondary leaver workers in general. Furthermore, return to schooling for the male is $6 \%$ higher compared to that of the female. That is, the return to education of the male is $19.2 \%$, whereas the female gets only $13.2 \%$.

Similarly, senior high school workers also have a benefit by continuing to secondary school from junior high school. From Fig. 8, the return to education using the level of education as a proxy is $9.4 \%$ in general, where for males it is $10.2 \%$ and females $7.6 \%$.

Junior high school workers also indicate the same result with the return to education up to $6.1 \%$ for females and $4.8 \%$ for males, if they continue to study from primary school to junior high school. Unlike other levels of education where the male gets a higher return to education, return to education for the female is slightly higher by $1.3 \%$.

Similar to using years of schooling as a proxy, using the level of education as a proxy also indicates that urban workers get higher salaries than their counterparts in 
the rural area by around $13.7 \%$. This number is also almost the same as the previous one using years of schooling as a proxy which is around $13.5 \%$.

\subsection{Discussion}

In this study, both the full discounting method and the Mincer earnings equation method have been applied to examine the return to education in Indonesia. Table 8 consists of a summary of the return to education from both analyses.

From Table 8, the result of regression in the Mincer earnings equation using years of schooling as a proxy indicates the return to education in Indonesia is around $8.9 \%$ on average. The Mincer equation is used as a benchmark since this method is the most widely used instrument to analyze the return to education. If we use the level of education as a proxy, the result in column (2) indicates that the return to higher education is around $15 \%$, which is the highest amongst other levels of education. However, the result of the implicit return to higher education from SWE estimation in column (1) is also $15 \%$. This finding indicates the similarity in results between using the level of education as a proxy in the OLS Mincer earnings equation and the implicit return to education through earnings difference from SWE analysis.

The pattern of return to education from both analyses also exhibits similarities where junior high school yields the lowest rate of return in all categories, and the second lowest is senior high school. This pattern applies to all classifications, such as gender and locations. For example, the result of the Mincer earnings equation analysis in column (2) indicates that the return to education for junior high school, senior high school, and college is $6.1 \%, 9.4 \%$, and $14.8 \%$, respectively. Referring to implicit return to education using SWE estimation, the result, as shown in column (1), indicates that junior high school, senior high school, and the college yield 7.6\%, 11.65\%, and $15.1 \%$, respectively. Similarly, in the male groups, the result of the Mincer earnings equation as shown in column (4) indicates that junior high school, senior high school, and college yield 4.8\%, 10.2\% and 19.2\%; whereas, implicit return to education using the SWE estimation as shown in column (3) yields $4.9 \%, 11.1 \%$, and $18.3 \%$, respectively.

If we move on to the full discounting method analysis, it exhibits more comprehensive results as it exposes a few scenarios. This study applies four scenarios, from low cost of colleges for public colleges to high cost of colleges for private colleges (see Table 6). As a result, the rate of return to education varies widely. Moreover, this method emphasizes the rate of return of monetary value invested in education rather than merely analyzing it through time spent for continuing schooling. Therefore, using NPV analysis, we can find the value of the investment in education in monetary value as well as how long a person needs gain a return on their education investment.

With the assumption of low cost of colleges, the return to education varies around 7.7-9.6\% amongst all categories. The highest rate is for the male group. This category provides almost 55\% of return, which amounts to Rp663 million (about USD 55,816) at present value. This category has the fastest BEP for just 10 years. It means that a man in this category who invests his money to attain a college degree will only take around 10 years to return his investment after working as a college graduate. 


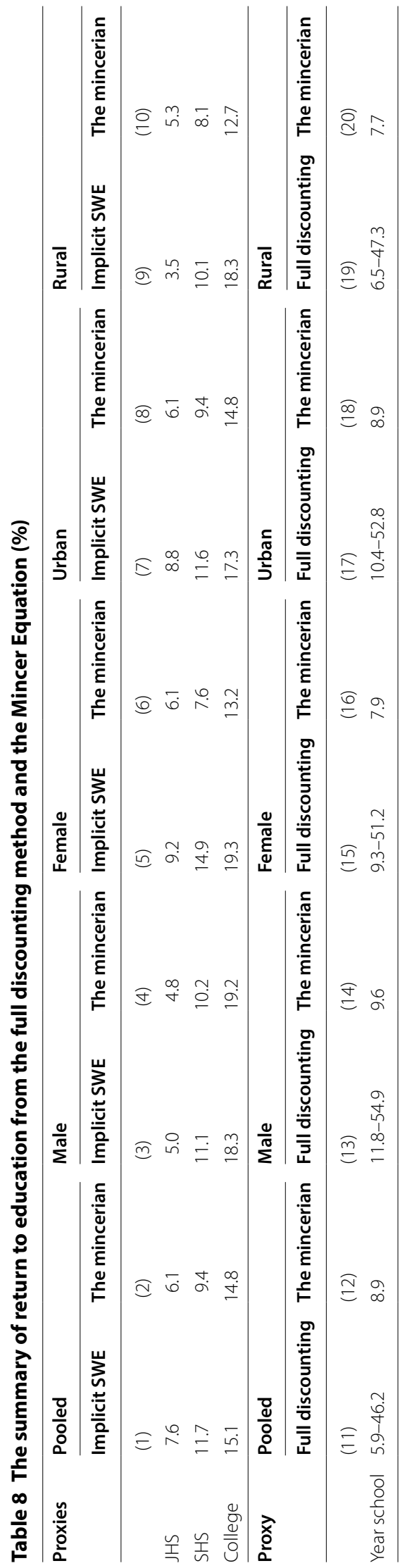


Nonetheless, there are at least two major limitations in this study that could be addressed in future research. First, the implementation of SWE using the median solely to estimate synthetic work-life earnings may be problematic. Unlike the Mincerian method, which uses the conventional econometric method, the use of SWE based on the median is unpopular and causes a lacks of information regarding sampling variation and population inference. To anticipate these issues, implementing other quartiles such as low at $25 \%$ quartile and high at $75 \%$ quartile can enhance the analysis, thus informing more comprehensive results for decision-making. Secondly, the data to estimate more robust results from SWE require a vast sample from each category and educational level. Incorporating other data sources such as Indonesia Labor Force Survey (SAKERNAS) published by the Statistics Indonesia should be considered for future studies.

\section{Conclusion}

This paper mainly discusses the return to education in higher education in Indonesia. Two approaches are utilized when analyzing the return to education in Indonesia, namely the Mincer earnings equation method and the full discounting method. The full discounting method is one technique for examining the return to education. Although many researchers mainly depend on the Mincer earnings equation analysis through econometrics, the full discounting method can be a substitution.

Before examining the return to education through the full discounting method, the first step was constructing work-life earnings estimation using SWE estimation. The second step was analyzing the IRR and NPV approaches.

From the SWE estimation, this research found that college graduate workers earn about a $60 \%$ higher salary than that of secondary school leaver workers. With four years to complete a college degree, this figure indicates that the return to higher education is around 15\%, which is similar to the result of the Mincer earnings equation analysis.

The SWE estimation also discovers that male workers earn more compared to female workers. This result supports the idea that most male workers represent the head of the household. Many employers consider giving additional allowance for their families through the head of households. However, the earnings difference between male and female workers decreases considerably as the level of education increases. This indicates that education can alleviate the power of bargain for a higher salary for female workers, so that their earnings will approach being equal in amount to the earnings of male workers.

Geographically, there are also differences between urban workers and rural workers, where the workers who work in the city will earn more than those in the rural area. Using SWE analysis, it is noticed that the gap of earnings is more significant for college graduate workers at around $20 \%$, which explains the tendency for workers to migrate from the rural area to urban areas such as Jakarta, the capital city, and other big cities in Indonesia. This finding is also supported by the result of the Mincer earnings equation method, where the return to education of urban workers is relatively higher compared to those who work in rural areas.

In terms of the return to education, both SWE analysis and the Mincer earnings equation method indicate an increasing trend as the level of education increases. In this case, becoming college graduate workers will be more advantageous compared to working 
directly after finishing secondary school. Likewise, secondary leavers have a higher rate of return compared to those who only finish their education in junior high school. These findings are in line with Purnastuti et al. (2013) empirical evidence that indicates a similar trend. Moreover, this study exhibits the differences in return to education between males and females as well as their locations.

The similarities of the Mincer earnings regression and SWE analysis in both the results and patterns of return to education in Indonesia confirms Psacharopoulus' (1995) argument that the Mincer earnings equation assumes a flat age-earnings profile: where the rate of return is simply the earnings benefit from continuing education divided by the number of years of schooling and previous earning.

Moreover, SWE analysis complements the full discounting method to examine the financial value of the investment. Using full discounting analysis, this study finds that investing in tertiary education in Indonesia can be relatively profitable, with the rate of return up to $46.2 \%$. At this rate, using NPV analysis, one can pay back all the expenditure to get a college degree within 14 years. However, this depends heavily on the choice of the college and the class of work. The median workers who graduated from the high-cost private college will only generate less than a $6 \%$ rate of return. NPV analysis indicates that it will take around 33 years before all the cost of attending a college can be entirely redeemed.

Therefore, for the students who can enroll in public colleges that are highly subsidized with a lower cost of living, investing time and money in tertiary education will be promising. Lifestyle choice also contributes to the total cost of college. Mainly, accommodation such as lodging and food take the most significant portion compared to other components.

On the contrary, if we assume that there is no subsidy for prospective students to continue their education to the tertiary level, as in the case of private universities with a higher cost of living, the situation will not be beneficial. For example, if we compare the interest rate of government bonds in Indonesia that reach $8.5 \%$ on average, this should make one think again to invest one's own money to enroll in a college.

To solve this problem moving forward, the government supports, especially for students from low-income families, become necessary. Other than the tuition fee waiver, providing affordable lodging is also an alternative solution to alleviate the high cost of tertiary education in Indonesia.

\section{Abbreviations}

IFLS: Indonesia family life survey; SWE: Synthetic work-life earnings; IRR: Internal rate of return; NPV: Net present value; BEP: Break-even point; OLS: Ordinary least square.

\section{Acknowledgements}

The author would like to express sincere gratitude to the Indonesia Endowment Fund for Education Institution [Lembaga Pengelola Dana Pendidikan (LPDP)] for financial support to seek a doctoral degree from Nagoya University, as well as the helpful comments from all reviewers.

\section{Authors' contributions}

Yubilianto designed the study, processed and interpreted the data, wrote the manuscript, and approved the final manuscript.

\section{Funding}

Not applicable. 


\section{Availability of data and materials}

The datasets generated and/or analyzed in this study are provided by RAND, https://www.rand.org/well-being/socia l-and-behavioral-policy/data/FLS/IFLS/download.html.

\section{Competing interests}

The author declares no competing interests.

\section{Author details}

1 Graduate School of International Development (GSID), Nagoya University, Furo-cho, Chikusa-ku, Nagoya 464-8601, Japan. ${ }^{2}$ Ministry of Finance of Republic of Indonesia, Financial Education and Training Agency, Purnawarman No 99 Kebayoran Baru, Jakarta Selatan, DKI Jakarta, Indonesia.

Received: 18 April 2019 Revised: 12 January 2020 Accepted: 11 February 2020

Published online: 25 February 2020

\section{References}

Badan Pusat Statistik (2019) Rata-Rata Pengeluaran per Kapita Sebulan Menurut Kelompok Barang (Rupiah). http://www. bps.go.id. Accessed 4 Apr 2019

Becker G (1962) Investment in human capital: a theoretical analysis. J Political Econ 70:9-49. https://doi. org/10.1086/258724

Becker G (1964) Human capital: a theoretical and empirical analysis with special reference to education. Columbia University Press, New York

Card D (1999) "The causal effect of education on earnings" in handbook of labor economics, vol 3A. Elsevier, Amsterdam

Chen SH (2002) Is investing college education risky? labor and demography 0202001. University Library of Munich, Germany

Chimombo J (2005) Quantity versus quality in education: case studies in Malawi. Int Rev of Educ. 51:155-172. https://doi. org/10.1007/s11159-005-1842-8

Comola M, de Mello L (2010) Educational attainment and selection into the labor market: the determinant of employment and earnings in Indonesia. Paris-Jourdan Sci Econ Working Paper, Paris 2010-06

Deolalikar AB (1993) Gender differences in the returns to schooling and in school enrollment rates in Indonesia. J Human Res 28(4):899-932

Duflo E (2001) Schooling and labor market consequences of school construction in Indonesia: evidence from an unusual policy experiment. Am Econ Rev 91(4):795-813

Dumauli MT (2015) Estimate of the private return on education in indonesia: evidence from sibling data. Int J Edu Dev 42(C):14-24. https://doi.org/10.1016/j.ijedudev.2015.02.012

El-Hamidi F (2005) General or vocational? evidence on school choice, returns, and "Sheep Skin" effects from Egypt 1998. Paper presented at the Twenty-Fifth Annual Meeting of the mid east econ assoc, Allied Soc Sci Assoc., Philadelphia Pennsylvania, 7-9

Julian TA, Kominski RA (2011) Education and synthetic work-life earnings estimates. Census Bureau, Washington, DC

Kantrowitz M (2007) The financial value of a higher education. J Stud Financial Aid 37(1):19-27

Kimenyi MS, Mwabu G, Manda DK (2006) Human capital externalities and private returns to education in Kenya. Eastern Econ J 32(3):493-513

Kurihara Y, Takaya S, Harui H, Kamae H (2008) Info tech and econ dev. Inf Sci Ref, New York

Layard R, Psacharopoulos G (1979) Human capital and earnings: british evidence and a critique. Rev of Econ Studied XLVI 3:485-503

Mincer Jacob (1974) Schooling, experience, and earnings. Columbia University Press, New York

Ministry of research, technology and higher education (2015). Ministry of research, technology and higher education decree number 22/2015. https://www.ristekdikti.go.id. Accessed 4 Apr 2019

Montenegro CE, Patrinos HA (2014) Comparable estimates of returns to schooling around the world. World Bank Pol Res Working Paper Series 7020

Patrinos HA (2016) Estimating the return to schooling using the mincer equation. IZA World of Labor. https://doi. org/10.15185/izawol.278

Patrinos HA, Ridao-Cano C, Sakellariou C (2006) Estimating the Returns to education: accounting for heterogeneity in ability. World Bank Pol Res Working Paper 4040

Psacharopoulos G (1972) The Economic returns to higher education in twenty-five countries. High Educ 1:141. https:// doi.org/10.1007/BF00139661

Psacharopoulos G (1981) Returns to Investment in education: a global update. World Dev 22(9):1325-1343

Psacharopoulos G (1985) Returns to education: a further International update and implications. The J of Human Res 20(4) (Autumn, 1985), 583-604

Psacharopoulos G (1994) Returns to Investment in Education: A global update. world dev 22(9) 1325-1343 https://doi. org/10.1016/0305-750X(94)90007-8

Psacharopoulos G (1995) The profitability of investment in education: concepts and methods. World Bank, Human Cap Dev and Op Pol Working Paper No 63

Psacharopoulos G, Mattson R (1998) Estimating the returns to education: a sensitivity analysis of methods and sample size. J Educ Dev Adm 12(3):271-287

Psacharopoulos G, Patrinos H (2004) Returns to investment in education: a further update. Educ Econ 12(2):111-134

Psacharopoulos G, Patrinos HA (2018) Returns to investment in education: a decennial review of the global literature. Educ Econ 26(5):445-458. https://doi.org/10.1080/09645292.2018.1484426 
Purnastuti L, Paul WM, Salim R (2013) Declining rates of return to education: evidence for Indonesia. B Ind Econ Studies 49(2):213-236. https://doi.org/10.1080/00074918.2013.809842

RAND (2016) The fifth wave of the Indonesia family life survey (IFLS5): overview and field report. https://www.rand.org. Accessed 4 Apr 2019

Sakellariou C (2003) Rates of return to investments in formal and technical/vocational education in Singapore. Edu Econ 11(1):73-87

Wicaksono TY, Friawan D (2008) Recent developments of Higher education in Indonesia: issues and challenges. Paper presented at Conference on financing higher education and economic development in East Asia, DPU/EABER, Bangkok, p p16-17

\section{Publisher's Note}

Springer Nature remains neutral with regard to jurisdictional claims in published maps and institutional affiliations.

Submit your manuscript to a SpringerOpen ${ }^{0}$ journal and benefit from:

- Convenient online submission

- Rigorous peer review

- Open access: articles freely available online

- High visibility within the field

- Retaining the copyright to your article

Submit your next manuscript at $\boldsymbol{\nabla}$ springeropen.com 